\title{
What Need is There for an Environmental Aesthetics?
}

\author{
Karsten Harries
}

\begin{abstract}
Aвstract The answer to the question posed in the title is by no means obvious. That we need to protect our environment has indeed become evident. But what, if anything, does aesthetics have to contribute towards meeting that need? Looking at aesthetics, as it has evolved ever since Baumgarten, the answer would seem to be: very little. Environmental concerns, important as they are, would seem to have no place in aesthetics, so understood. Is there then any reason for those concerned with the future of the environment to look to aesthetics for help? It would seem that what is needed is not the consolation offered by edifying experience or beautiful illusion that willingly turns its back on ugly reality; rather, we need active intervention, based on solid information, which will change the world for the better. Can aesthetics, can art, make an effective contribution towards meeting that need? In this connection we should consider the following: why, if the problems that face us are indeed so evident, do our responses remain so half-hearted? The main problem would not seem to be a lack of information. To change the way we relate to the environment we need more than just cold reason: we need to experience what transcends the reach of such reason. What is required is a change of heart. But how do hearts change? Here an environmental aesthetics can make a contribution, but an aesthetics so fundamentally transformed that we may well wonder whether aesthetics remains an appropriate name. Schiller's Letters on the Aesthetic Education of Man provides some significant pointers. We are also in need of a changed understanding of art and its relationship to nature.

KEYWORDS Kant, Hegel, natural beauty, art and nature, environmental aesthetics, climate change
\end{abstract}

\section{1}

What need is there for an environmental aesthetics? The answer to that question is by no means obvious. To be sure, that we need to protect our environment has become a cliché that I am just a bit wary about repeating it here - the statement hardly bears much discussion any longer. Is it not obvious that we need to make sure that all those natural resources on which we depend for our survival will continue to be available, not just to us, but to future generations? And when we think here of natural resources, we should consider them in the widest possible sense so that they include what the ancients thought of as the four elements, air, water, earth and fire. And here I invite you to think of them in their modern transformations. Even space has become an increasingly scarce resource. But if all this is indeed obvious, if the facts today speak loudly enough, it is not at all clear why we should be in need of an environmental aesthetics? What, if anything, does aesthetics have to contribute to our attempt to meet the environmental problems we face? 
A brief look at how aesthetics has evolved ever since Alexander Gottlieb Baumgarten founded this philosophical discipline in his dissertation, Meditationes de nonnullis ad poema pertinentibus of 1735 , and coined the term, suggests: very little. Environmental concerns, important as they are, not only have been given little attention by aesthetics, but it is not clear what sense aesthetics, as it has evolved, can make of an environmental aesthetics. Should such an aesthetics look at the environment through the lens provided by the work of art? The fact that aesthetics has had so little to say about the environment should give us pause. Is this just a matter of neglect of an important topic or is there something about aesthetics that renders the very idea of environmental aesthetics problematic?

Consider, for example, the beginning of Hegel's Lectures on Aesthetics - with good reason Heidegger called them the "most comprehensive reflection on the nature of art that the West possesses"1:

The present course of lectures deals with 'Aesthetics'. Their subject is the wide realm of the beautiful, and more particularly, their province is Art - we may restrict it indeed to Fine Art. ${ }^{2}$

We should note the restriction: nature, the natural environment, is hardly a proper subject for aesthetics, as Hegel understood it. The proper province of aesthetics is Fine Art. And Hegel did not think his restriction of the discipline to Fine Art at all arbitrary, but took it to be demanded by the very nature of "aesthetics."

And did he not have good reason to exclude the beauty of nature from his Aesthetics? Hegel justifies this exclusion by insisting that "the beauty of art is the beauty that is born - born again, that is - of the mind; and by as much as the mind and its products are higher than nature and its appearances, by so much the beauty of art is higher than the beauty of Nature. Indeed, if we look at it formally, i.e. only considering in what way it exists, not what there is in it, even a silly fancy such as may pass through a man's head is higher than any product of nature." ${ }^{3}$ The young Hegel's response to the Alps is telling:

Neither the eye nor the imagination finds in these formless masses any point on which it could rest with pleasure or where they might be engaged or find something to play with. Only the mineralogist finds here material for insufficient conjectures concerning the revolutions of these mountain ranges. Reason finds in the thought of the permanence of these mountains or in the kind of sublimity that is ascribed to them nothing that impresses it, that demands wonder and admiration. Seeing these dead masses gave me nothing but the monotonous and in time boring idea: this is the way it is. ${ }^{4}$ 
Nature is thought here, in a characteristically modern fashion, to be mute material to be understood, appropriated, and used by us as we see fit. A crystal can be called beautiful, but the beauty of its geometric faces is really the product of our own spirit, which recognizes in their geometry something of itself. With greater justice a city, or just a ploughed field, can be called beautiful, for in both cases human beings have labored to impose an order on matter. Nature has been subjected to the human spirit. Considered just in itself, Hegel insists, nature cannot be considered beautiful.

Mind, and mind only, is capable of truth, and comprehends in itself all that is, so that whatever is beautiful can only be really and truly beautiful as partaking in this higher element and as created thereby. In this sense the beauty of nature reveals itself as but a reflection of the beauty which belongs to the mind, as an imperfect, incomplete mode of being, as a mode whose really substantial element is contained in the mind itself. ${ }^{5}$

Hegel knows of course that human beings are more than just minds. They, too, are animals and as such part of and dependent on nature. But if human beings are animals and as such part of nature, they are animals that by virtue of their reason raise themselves above nature, become conscious of it, experience it, including their own nature, as not simply given, but as material to be understood, shaped, and bent to their will, instructed by their reason. Their spirit places human beings in opposition to nature, even their own nature, and demands mastery over it. In something as simple as a child throwing stones into the water and enjoying the rings formed, Hegel finds evidence of this drive. Already in such childish play human beings seek to appropriate the natural given by transforming it in their own image, and this means first of all in the image of the human spirit. History is understood by Hegel as the progress of such appropriation; our modern age as the culmination of that process. Have we not come close today to realizing the Cartesian promise that our science and technology would render us the masters and possessors of nature?

Art, too, is part of the effort to make the natural and sensible our own, to rob it of its character of being a mute, alien other by investing it with the aura of the human, and thus to help transform the earth into a dwelling place fit for human beings, into something that deserves to be called home. The goal of art, too, is such a humanization of the sensible, where humanization here means spiritualization. So understood, art in its origin, where Hegel is thinking first of all of architecture, prefigures 
technology, which allows for an ever more effective mastery of nature and for that very reason eventually must take its leave from art, overtake it, and leave it behind. Thus left behind, art in turn takes its leave from magic and religion, as it ever more decisively turns its back on reality, creating a second reality. So understood, the progress of spirit leads art inevitably towards art for art's sake. Instead of promising mastery of the world, it now promises the creation of a second reality that, imbued with spirit by spirit, offers us compensation for the muteness of spiritless nature.

Here we have a key to Hegel's thesis of the death of art in what he took to be its highest sense. Closely linked to religion and magic, art once was experienced as a privileged mode of revealing what most profoundly mattered. For us moderns, art has lost this function. We no longer fall on our knees before sculptures or statues. The evolution of spirit has reached a point where the claims of art to provide a privileged access to truth can no longer be taken seriously. What does truth matter to art for art's sake? What does art still have to contribute towards the solution of the urgent problems we all face?

Hegel's understanding of the progress and end of art was hardly derived from a careful examination of the evidence provided by the history of art. It represents rather an, at times, willful fitting of the evidence into a schema that he derived from his own determination of the essence of art and its place in the progress of spirit. But regardless of details, in its essentials that determination is difficult to get around. If we grant Hegel that history has been ruled by the progress of spirit and freedom, do we not grant him the substance of his case? If the progress of spirit demands that the individual liberate him- or herself ever more decisively from the accidents of whatever happens to be the case, then our real home should not be sought by looking to nature, say by looking to the aura of some particular place and its genius loci. Must our real home not be a spiritual home to which nothing sensible can finally do justice? Our environment comes closest to meeting this demand when we experience it, not as nature, but as artifact. Consider in this connection the widespread insistence on the inessential nature of what is considered the accident of location, birth, gender, and race. Is the attempt to discover one's home in a particular landscape not born of a nostalgia that we should not allow to rule our lives and build us our homes? And is the same not true of our bodies? This at least was what the French concept artist, who calls herself Saint Orlan, tried to prove when, with the help of plastic surgery and psychotherapy, she tried to remake herself into an altogether new 
person and wanted the French government to officially recognize the change. And would that not mean true autonomy, freedom finally no longer limited by any supposedly natural givens? The Enlightenment gave birth to the confidence that, bound ever more only by the authority of our own reason, we moderns find ourselves on the threshold of true autonomy. Our aggressive appropriation and transformation of the environment appears from this perspective as but an aspect of humanity's coming of age. Are there not many today, who feel already more at home in cyberspace than in any natural environment? So understood, environmental problems need of course to be assessed, confronted, and addressed. We still depend on the earth. This we will not be able to deny. But such dependence should be accepted and dealt with as a fact, and not invested with a spiritual aura. We should look to science and technology for solutions, not to art. What then do we have to learn from aesthetics?

St. Orlan's attempt to remake herself into a new person, is an extreme expression, perhaps a reductio ad absurdum, of the spirit of the Enlightenment in that it raises the question: what content can we give to the I that here seeks to become another? Autonomy means giving oneself the law that determines what is to be done. But where does a spirit, which looks at all natural givens as material to be manipulated, find that law? In pure reason?

\section{2}

Anyone with an interest in developing an environmental aesthetics has to take issue with Hegel. And not just with Hegel, but with a way of thinking about beauty that is as old as Plato. Consider this passage from Plato's Philebus, a passage that makes me think of an artist like Mondrian:

I do not mean by beauty of form such beauty as that of animals or pictures, which the many would suppose to be my meaning; but says the argument, understand me to mean straight lines and circles, and the plane or solid figures, which are formed by turning lathes and rulers and measures of angles - for these I affirm to be not only relatively beautiful, like other things, but they are eternally or absolutely beautiful, and they have peculiar pleasures, quite unlike the pleasures of scratching. ${ }^{6}$

The beauty of animals or pictures is here contrasted with the beauty of simple inorganic forms, above all the beauty of circle and sphere, the most potent figures of plenitude; theirs is a beauty that is created, not by the body, but by the spirit. Indeed, in creating such beauty, the body is likely to prove a hindrance. Try to draw a straight line with your free hand. 
This Platonism has surfaced again and again, especially in the twentieth century. It came indeed close to evolving into the aesthetic of the modern movement. Mondrian deserves special mention in this connection, as do Gropius, Mies van der Rohe, and Le Corbusier among architects. Here, a statement from Corbusier's and Ozenfant's programmatic essay "Purism": "Nothing is worthwhile which is not general, nothing is worthwhile which is not transmittable. We have attempted to establish an aesthetic that is rational and therefore human." ${ }^{17}$ Quite in the spirit of Plato and still Hegel, what is worthwhile in art here is equated with what is general, rational, and can be understood by everyone. This presupposes that there is a universal language of art, a language not tied to a particular landscape, a particular climate, but cosmopolitan in its very essence. Note the presupposed, but profoundly questionable equation of what is human with what is rational: the presupposition is that the spirit provides a timelessly valid vocabulary on which the artist can draw to generate an art that will have a truly universal and timeless significance. Such beauty defeats the terror of time.

What makes beauty in this sense questionable is the fact that it demands a downgrading of the individual and of the body. Thus, it threatens to do violence to the whole human being and elides rather than confronts our mortal condition. At issue here is our understanding of ourselves and how we should relate to nature, including our own nature: the problem we confront is fundamentally a problem of ethics, and at the center of this problem is the difficulty we have accepting our mortality.

\section{3}

In this connection it is of interest to ask: what kind of thing did Baumgarten have in mind when founding philosophical aesthetics? When I ask you to think of something beautiful, what comes to mind first? You might think of a person, or a flower, or a work of art. In each case the experience exhibits a different structure, and we should also ask ourselves what the family resemblance is that lets us call each, person, flower, or artwork beautiful. As Hegel was to do later, Baumgarten thought it obvious that aesthetics should look first of all to an artwork, in his case a poem.

Is it obvious? I think it important to challenge that way of thinking. I do not think that the focus on the artwork leads us to an adequate understanding of either beauty or, in the end, even of art. In this connection it is helpful to contrast Baumgarten's and Hegel's approaches to beauty with that of Kant. When Kant looks for examples of something beautiful he thinks 
first of all of beautiful nature. Invoking the medieval metaphor of the book of nature, ${ }^{8}$ Kant still experiences beautiful nature as preserving something of the aura of the sacred. What first comes to his mind is a flower. And Kant further insists that the beauty of art is dependent upon the beauty of nature, a beauty of which we are most definitely not the authors and which he therefore places far above all artificial beauty. And thus he insists that it is nature that, though the genius, gives the rule to art. ${ }^{9}$

Let me return to the metaphor of the book of nature. To liken nature to a book is to suggest that we experience in it something like a transcendent spirit speaking to our own spirit. Experiencing beautiful nature we feel at home in it. And does something of this sort not hold for everything that can give meaning to our lives? We begin to glimpse here something of the importance of nature, not just to our physical, but to our spiritual well being. If aesthetics has something to contribute to the environmental problems we face, it is to Kant that it should look rather than to a tradition that finds beauty first of all in the artificial, a tradition that stretches from Baumgarten to Hegel and continues right to the present. That is to say, we have to consider carefully the relationship of beauty to nature.

\section{4}

For those concerned with the future of the environment, is there, I asked, any reason to look to aesthetics for help? What is needed, it would seem, is not the consolation offered by edifying experiences or beautiful illusions that turn their back on ugly reality. Rather, we need active intervention, based on solid information, which will change the world for the better. Can aesthetics, can art, make an effective contribution towards meeting that need? Do we not all know what the problems are and what needs to be done? Our task is to do it.

Why, then, do we not do more? To change the way we relate to the environment we need more than just cold reason: we need to be touched by something that transcends the reach of such reason. Reason serves a narrow self-interest as readily as a concern for future generations. Our only hope is, I will argue, a change of heart that lets us reckon differently with time. But how do hearts change? It is here, I want to suggest, that an environmental aesthetics can perhaps make a contribution. But this would have to be an aesthetics that is very different from the aesthetics inaugurated by Baumgarten. So different, in fact, that we may well wonder whether "aesthetics" even remains an appropriate name. Among other things, this would have to be an aesthetics that reckons differently 
with time, that does not follow Plato and place beauty, or more broadly the aesthetic object, in opposition to time and therefore to nature. Kant's Critique of Judgment provides some significant pointers despite its analysis of the disinterested character of the aesthetic judgment, which, following the tradition, would have us think beauty in opposition to time. As does Friedrich Schiller's Letters on the Aesthetic Education of Man, so obviously dependent on the former. We need a different way of experiencing the significance of nature, which would place the beauty of nature above the beauty of art. An environmental aesthetics can help prepare for that change.

\section{5}

Given a still expanding world population, coupled with a still rising life expectancy and demands for an ever higher standard of living, the conclusion seems inevitable: the road on which the world has been traveling has to lead to disaster, or rather disasters. Not only the expected disasters, such as mass starvation, wars for land, a deteriorating environment that will render clean water, air, and soil, not to speak of relatively unspoiled nature, let alone wilderness, increasingly scarce resources. But it might also lead to moral disaster. And if the first threat is more obvious, the second seems to me equally serious.

How will we respond to ever more pressing environmental problems? I can envision two scenarios: one marked by an ever increasing selfishness, an ever more aggressive and desperate defense of one's own cherished standard of living, which has to mean the increasing deterioration of what we can perhaps call our moral environment. The other marked by a gradually diminishing selfishness, by a gradual improvement of our moral environment.

The first is all too easy to envision: a brave new world, the haves are building fences around themselves to shut out the have-nots, hiring guards or armies as the case may be. The growing popularity of the selfenclosed armed residential enclave, not only in the United States, can serve as a dismal prophetic emblem of a world turned into a nightmare by our way of life. In bad dreams I see the American landscape transformed into countless condominiums, spreading across the land, from sea to shining sea, although on such a country God would not have shed his grace.

Privileged as we are to live in industrially advanced societies, can we intelligently wish for most of the world's population to emulate the way we pursue what we take to be the good life? But if not, can we ourselves 
in good conscience continue in that pursuit? Kant held that we are never to act otherwise than so that we could also will that our maxims should become a universal law. But if so, it seems clear that many of the maxims by which we govern our everyday life do not permit such generalization, for they are ruled rather by a selfishness that refuses to look abroad and to plan very far ahead. Much of our built environment, including the look of our cities and suburbs, presupposes such selfishness. Think of energy-guzzling skyscrapers or of the McMansions that we now see in America obscenely sprouting in suburb after suburb. As I suggested before, we need to learn to understand space, too, as a scarce resource.

But do we need to moralize? Is it not in our own best interest to preserve, for ourselves and for those who will succeed us, an environment that will enable us to sustain the kind of life we desire for ourselves? Of course, the answer depends on how narrowly we are to understand personal interest. I can imagine individuals so preoccupied with themselves that they really feel: after me the deluge. If what I understand to be my personal interest is circumscribed by my life and death, then what happens to those whose lives no longer intersect with my own, those who, after my death, will have to cope with problems I may have helped to create, need not concern me. This, to be sure, would be to presuppose what I consider an unacceptably narrow understanding of personal interest and of the person. I am also convinced that such a narrowly construed self-interest finally has to rob our own life of its value. Nihilism and such self-centeredness belong together. Only a very short-sighted selfishness will refuse to recognize that we need to consider the environment as an increasingly scarce resource, which by its very nature does not belong to me or to us, to Americans or Chinese, but to all. I also recognize, however, that someone sufficiently self-centered need not be convinced by my argument. That, as I claimed earlier, would require more than argument, would require a change of heart. I may judge such selfishness evil, perhaps even the root of all evil, but such a judgment presupposes that I do not understand myself as in any way a self-sufficient whole, but as part of something larger. And while I expect that most, perhaps all of you, will in some measure agree with me, I am also convinced that there is no argument strong enough to force a dissenting egoist to change his or her mind.

I said that most of you would agree with me that in order to live meaningful lives we must understand ourselves as parts of something larger. Was I entitled to that assertion? To test it, I offer you the following thought experiment: 
Many of us love to wonder and worry about impending cosmic catastrophes, such as the ultimate fate of the sun and its consequences for our earth. There is indeed something sublime about such gloomy thoughts, which let us think of our homelessness in an uncaring universe, only to lead us back to our precious selves. Suppose the threat were not quite so far off. Some years ago there were disturbing reports of an asteroid that might hit the earth some time around 2032. To be sure, the probability was supposed to be only 1 in 100 . But that still seems much too great, especially when coupled with reports that a significantly smaller asteroid was responsible for the extinction of the dinosaurs many millions of years ago. Were we headed for a similar fate? Fortunately recalculations of the asteroid's orbit showed that there was no danger after all.

But suppose such a collision were in fact imminent; suppose it did promise to put an end to humanity. Would this not have an enormous impact on the way we feel about ourselves and our fragile relations with others? To plan for the distant future would suddenly make little sense. The present would become more important. Carpe diem! And such certainty would also change the way we build, if indeed we retained a will to build at all: great architecture and city planning presuppose and speak of an optimism and a care that reach into a future that architects and city planners will no longer live to see. But what sense would it make to build for a future that would never arrive? Given such conviction, our lives would inevitably become more self-centered and present-centered. Ecological concerns, say, worries about global warming, would lose their point. We would all feel lonelier than before, even as we might turn more desperately to others.

To bring the point of this thought experiment into still sharper focus, indulge me in this science fiction. Imagine someone who had entered a bargain with the devil, who had promised this individual a happy long life followed by a good death, and had asked in return that he be allowed to implant a doomsday device in our Faustian hero such that his death would be followed immediately by the destruction of all life on this earth, although his own life would, by the terms of the bargain, not be shortened at all. Suppose you had struck such a bargain with the devil? How would you be affected by the knowledge that with your death all life would end, and all that would be left would be a lifeless earth? Now, imagine that it is just the end to all human life? Would you feel differently? I can imagine a Nero or a Hitler welcoming such thoughts. Would they be objectively wrong to do so? I would not hesitate to call them evil. And I find it difficult to imagine them in no other state than desperately unhappy. 
How would you be affected by the certainty that with your death life on earth would end? If you understand your own death to circumscribe what matters to you, why should it make any difference at all? Would your life not remain pretty much the same? Why should it concern you how the world will look after you are gone? To most of us it would of course make an enormous difference, which shows that we recognize that not caring for those who will outlive us diminishes our own life. We demonstrate such recognition whenever we plan for a future after our death, for example when we take out life insurance; or when we create a work of art to give joy to those who will come after us; or when we plan a city. Most of us would not consider these irrational acts. But if we do not consider such acts to be irrational, it has to mean that we project ourselves beyond our individual lives, that we acknowledge that the meaning of our individual death-bound lives depends crucially on our ability to place ourselves in an ongoing community. And if so, would we not want, or rather, feel a duty towards making sure that the environment will continue to speak to us of such a faith in the future? But the environment speaks to us most strongly in this way when we experience it as nature shaped by human work responsive to it. I use "landscape" here to mean nature transformed by human work, shaped by history and by planning for the future, quite aware of the artificiality of such usage and without investing too much in this particular word. You may well come up with a happier term, but as I am using the word here, "landscape" is opposed to "wilderness." What allows us to understand such landscapes is an ever changing figure-ground relationship: cities, villages, houses, roads, and fields present themselves as more or less permanent figures in the landscape. I want to claim that we all have a need for landscape so understood as well as a need to preserve it. Such figuration reinforces the legibility of the environment, makes it more homelike. To be sure, to a person who, to speak with Kierkegaard, had buried himself within himself, such landscapes, such figures of ongoing community would not matter.

\section{6}

I suggested that an environmental aesthetics might contribute towards a change of heart that might make people more willing to support the institution of painful, but desperately needed measures to assure that the earth will remain a sustainable environment. What might such an environmental aesthetics look like? For one, it would not place artifice above nature. Rather it would recognize the dependence of the meaning of art, indeed of all meaning, on nature. 
Earlier I mentioned Kant, for whom nature still preserved something of the aura of the sacred. But does this not mean, one may want to object, that in this respect Kant still remains indebted to a fundamentally still medieval understanding of the beauty of nature, to which the Enlightenment and indeed Kant's own formal understanding of beauty were to put an end? Is any attempt to endow nature with something like the aura of the sacred not out of step with the spirit of modernity? I want to suggest that something like this is indeed what we are in need of.

Here it is instructive to consider a passage in Kant's Critique of Judgment, where he wonders how it would affect us to learn that the sound, which we thought to be the call of a nightingale, was in fact produced by a boy, who had been hired by an innkeeper on some beautiful summer evening in order to heighten the enjoyment of his guests. ${ }^{10}$ The assumption is that what is heard remains indistinguishable from the song of the true nightingale. From a purely aesthetic point of view, it would seem, there should be no reason to rank one above the other. And Hegel might well have preferred the simulacrum, since it demonstrates the skill of the human performer. Nevertheless, Kant suggests, once we learn of the deception, that which we hear loses its aura; we still hear the same melody, but now without the former interest and pleasure, which shows that more is involved in our appreciation of beautiful nature than just the appreciation of beautiful forms. What matters is that these forms are experienced as products of nature, as not born of artifice. Here something in nature is experienced as answering to our intellect and its demands. Spirit without seems to speak to our own spirit. In beautiful nature we thus feel at home. The beauty of the environment promises a spiritual homecoming to the earth.

But has Walter Benjamin not taught us to recognize the self-deception that supports such an experience? What sense can we still make of any talk of the spirit dwelling in nature? A religious person may once have had an answer. But has the progress of science not replaced the book of nature with an understanding of nature as the totality of essentially mute facts, to be used by us as we see fit and are able? More questions are raised by Kant's claim that "an immediate interest in the beauty of nature ... is always the mark of a good soul," that the appreciation of the beauty of nature is "akin to the moral feeling."11 How are we to understand such kinship?

What links the two is that both involve something like an experience of an incarnation of spirit in matter. To be sure, as Kant emphasizes, our science can know nothing of such an incarnation. For the same reason 
it can also not know anything of persons as persons. Freedom has no place in the world of science. And yet the experience of persons as responsible agents is a presupposition of any ethics. Morality presupposes an experience of others as persons deserving respect. But this is to say that we must be able to experience persons as more than just objects among objects, say as robots governed by computers so complicated that they successfully simulate human intelligence. The other must present him- or herself to me as spirit incarnated in this particular matter. To experience such an incarnation is to experience a person's special aura. Were I to learn that what I took to be a person were just some mechanical reproduction, I would no longer experience the aura that alone lets me recognize the other as a person, like myself. I would lose what allows me to know that I am not alone.

But even if we grant that the recognition of persons presupposes an experience of aura that is more than just a registration of mute facts, that here we experience incarnations of spirit in matter, what justifies Kant's claim that recognition of beauty in nature, too, presupposes an openness to some spirit transcending our own? Kant might have answered that even though science cannot know anything resembling an incarnation of spirit in matter, its pursuit of truth nonetheless presupposes experiences of the intelligibility, or as he would put it, of the purposiveness of nature. Kant's theory of knowledge turns out to have its foundation in his aesthetics of nature. And this claim can be generalized: the Cartesian self-assertion that lets human beings oppose themselves to nature as its masters and possessors presupposes, not just sensation, but a perception of significant patterns or family resemblances, as Schopenhauer, and following him, Wittgenstein were to put it. All concept formation presupposes perceptions of meaning in matter, of meaning that cannot be manufactured, but must be received as a gift. There is thus an intimate link between my ability to appreciate the beauty of the natural environment and my ability to experience the other as a person. Both are perceptions of spirit incarnated in matter, answering to our own spirit. Both give us to understand that we are not lost in the world, but at home in it. Both persons and nature demand respect.

One might want to say at this point about nature something analogous to what Benjamin had to say about art in the age of its technical reproducibility: is the loss of aura not demanded by the spirit presiding over our age? Benjamin would seem to affirm this loss as a necessary byproduct of the progress of technology; and does technology, by promising to render us masters and possessors, not just of nature without, but of our 
own nature, not also promise true autonomy and happiness to all? This, to be sure, presupposes, as Benjamin reminds us, that a society is "mature enough to incorporate technology as its organ,"12 instead of allowing technology to become an instrument used by those in power to reduce human beings to human material.

But how are we to acquire the needed maturity? Reason alone has proved unable to secure it. In this connection it is interesting to note that Benjamin, too, found it difficult to let go of the aura, which, in "The Work of Art in the Age of Mechanical Reproduction," he seems so ready to relegate to a never to be recovered past. In that essay this is hinted at through an example, in which it is significant that it is taken not from art but from nature: "If, while resting on a summer afternoon, you follow with your eyes a mountain range on the horizon or a branch which casts its shadow over you, you experience the aura of those mountains, of that branch."13 Mountains or that branch hint at some elusive magical other. The seen material object is experienced as a figure of utopia.

Is it this figural significance of the perceived that the word "aura" is here meant to capture? The Greek "aura" meant "breath" or "breeze"; the Latin "aura" a gentle wind or current of air; and "aura" thus came to name the subtle emanation of some substance, for example the special odor of a rose. In this sense, an artificial rose can be said to lack the aura of the original. In all these cases, "aura" names a perhaps elusive, but definitely physical phenomenon, which can in principle be measured. Aura here has a material basis. That basis became more elusive, was spiritualized, when aura came to be understood in the 19th century as a subtle emanation around living beings. In that sense, one might speak of the special aura issuing from a charismatic person or from someone we love. And is there not a similarity between the aura of the beloved and the aura of that distant mountain range?

For Benjamin the paradigm behind all experiences of aura is the experience of another person: "Looking at someone carries the implicit expectation that our look will be returned by the object of our gaze. Where this expectation is met which, in the case of thought processes can apply equally to the look of the mind and to a glance (pure and simple), there is an experience of the aura to the fullest extent." ${ }^{14}$ There is a profound difference between experiencing the gaze of the other and experiencing the aura of a writer or a composer in one of his or her creations. When I experience the other person, the experience of his or her distinctive aura is the experience of an incarnation of spirit and matter so complete that there is no distance between the two. The mystery of aura is the mystery 
of such incarnation, which is fully realized when two lovers look into each other's eyes: "The person we look at, or who feels he is being looked at, looks at us in return." ${ }^{15}$ But something of the sort is present in every experience of aura: to experience the aura of something is to experience it as if it were another person, capable of speech. Benjamin no doubt would have us underscore the "as if": "Experience of the aura thus rests on the transportation of a response common in human relationships to the relationship between the inanimate or natural object and man."16 On this interpretation it is the human subject who invests an essentially mute nature with something like spirit or soul. But should we who are truly of this modern world not recognize that such an investment is at bottom a self-deception? Today, a child may still experience rocks and animals as animate, endowed with the power of speech; and fairy tales preserve traces of an older magical experience of the aura of all things. But is a presupposition of our science and technology not a reason, which has to render nature mute and meaningless? Such a reason cannot make sense of the phenomenon of aura except as a projection of meaning into matter, which, as such, lacks meaning. And are human beings not part of nature? The question returns us to Nietzsche's pronouncement in The Birth of Tragedy that only as an aesthetic phenomenon can human existence be justified.

What allows us, or Benjamin, in this age of the technical reproducibility, not just of works of art, but increasingly of everything, to hold on to a fundamental distinction between the aura of human beings and the aura of works of art and natural objects? Are human beings today not in danger of losing that special aura, which distinguishes persons from their simulacra? Think of artificial hearts! Of cloning! What, in principle, distinguishes a person from a robot with a computer brain?

\section{7}

One final comment. Returning once more to the title of this article: what need is there then for an environmental aesthetics? An environmental aesthetics, I have here suggested, is needed to help pry open a window or door in the architecture that the reason, which rightly rules over our science and technology, has built us; a window to a dimension of our experience and of reality that transcends the reach of such reason. I do not have time here to develop the suggestion that the environmental problems that we face similarly call for an aesthetic education. So let me conclude by returning to the definition of beauty as the object of love that Plato offers us in the Symposium. To experience the beauty of 
our environment is to love it somewhat as we love a cherished person. I was thinking of such a love when I was speaking of the change of heart required if our measures to protect the environment are not to remain half-hearted and insufficient.

\section{Notes}

1. Martin Heidegger, "Der Ursprung des Kunstwerkes," Holzwege (Frankfurt: Klostermann, 1950), 66; "The Origin of the Work of Art," Poetry, Language, Thought, trans. and intro. Albert Hofstadter (New York: Harper and Row, 1971), 77-78.

2. Georg Wilhelm Friedrich Hegel, Vorlesungen über die Aesthetik, vol. 12 of Jubiläumsausgabe, ed. Hermann Glockner (Stuttgart: Frommann, 1937), 19; “Introductory Lectures on Aesthetics," trans. Bernard Bosanquet (London: Penguin, 1993), 3 .

3. Hegel, Vorlesungen, vol. 12, 19; trans., 4.

4. Hegel, "Auszüge aus dem Tagebuch der Reise in die Berner Oberalpen (25. Juli bis August 1796)" Werke, vol. 1, Frühe Schriften, eds. Eva Moldenhauer and Karl Markus Michel (Frankfurt am Main: Suhrkamp 1971), 618.

5. Hegel, Vorlesungen, vol. 12, 21; trans. 4

6. Plato, Philebus, $51 \mathrm{c}-\mathrm{d}$, trans. Benjamin Jowett.

7. Le Corbusier and Ozenfant, "Purism," Modern Artists on Art, ed. Robert L. Herbert (Englewood Cliffs, NJ: Prentice Hall, 1964), 60.

8. Immanuel Kant, Kritik der Urteilskraft, A168/B170.

9. Kant, Kritik der Urteilskraft, A179/B181.

10. Kant, Kritik der Urteilskraft, A170-171/B172-173.

11. Kant, Kritik der Urteilskraft, A164/B166; trans. J. H. Bernard, Critique of Judgment (New York: Hafner, 1951), 141-143.

12. Walter Benjamin, "The Work of Art in the Age of Mechanical Reproduction," Illuminations, ed. with an introduction by Hannah Arendt, trans. Harry Zohn (New York: Schocken Books, 1968), 242.

13. Benjamin, "The Work of Art," 222-223.

14. Benjamin, "On Some Motifs in Baudelaire," Illuminations, 188.

15. Ibid.

16. Ibid. 